\title{
STRUCTURIZATION OF THE ARAL REGION SOIL BY POLYCOMPLEXES OF HUMIC ACIDS SALTS
}

\author{
S.M. Tazhibaeva, G.Seit, A.B. Orazymbetova, A.K. Tanybaeva, K.B. Musabekov, A.K. Kokanbaev
}

Structuring action of a sodium humate, polyethyleneimine and them complexes on the Aral region soil is investigated. It is shown that a sodium humate possess the big structuring action, rather than polyethyleneimine, however the effect of structurization increases at use of complexes a sodium humate - polyethyleneimine. Increase in structuring ability at introduction in soil of a mix the sodium-polymer humate is proved by occurrence of electrostatic contacts between amino groups of polyethyleneimine and carboxyl groups of a humate of sodium.

\section{УДК 541.64}

\section{2-ГИДРОКСИЭТИЛАКРИЛАТ ПЕН МЕТИЛМЕТАРКРИЛАТ ГИДРОГЕЛДЕРІНІН ІСІНУ ҚАБІЛЕТТІЛІГІНЕ ИОНДЫҚ КҮШТІН ӘСЕРІ}

\author{
А.К. Токтабаева, Р.Қ. Рахметуллаева, Г.А. Мун \\ Әл-Фараби атындағы Қазақ ұлттық университеті, Алматы қ., Қазақстан Республикасы, \\ a.toktabayeva@inbox.ru
}

ГЭА-ММА полимерлі гидрогельдердің ісіну дәрежесіне иондық күштің әсері зерттелген. ГЭА-ММА гидрогельдерінің контракциясын тудыру үшін иондық күшті және бастапқы мономерлік қосппның құрамын өзгерту арқылы құол жеткізуге болатыны көрсетілген.

Қазіргі таңда термосезімтал полимерлер арасында ғылыми және практикалық жағынан үлкен қызығушылық туғызатын, сулы ерітінділерінің төменгі критикалық еру температурасы (ТКЕТ) бар полимерлер жатады. Мұндай макромолекулалардың құрылымында суда ерігіштігін қамтамасыз ететін функционалды гидрофильді топтары, сонымен қатар гидрофобты фрагменттері болады. Температураны өсіргеннен гидрофобты әрекеттесулер артады және термосезімтал полимер - су жүйесінде әр түрлі критикалық құбылыстар жүреді: сызықты макромолекулалар үшін бұл екі фазаға жіктелумен жүреді - полимермен сұйытылған және қоюланған орта, полимерлі торлар үшін термоиндуцирленген коллапспен, басқаша айтқанда белгілі бір температурада ондаған және жүздеген рет гель көлемінің бірден сығылуымен жүреді /1-3/. Авторлармен радикалды сополимеризация әдісімен 2-гидроксиэтилакрилат (ГЭА) және метилметакрилат (ММА) негізінде жаңа суда ісінетін термосезімтал сополимерлер алынды /4/. Алынған гидрогельдер температураға сезімталдығы және оның өсуімен контракцияға ұшырайтыны көрсетілген. Осы жұмыста гидрогельдердің ісіну қабілеттілігіне иондық күштің әсері зерттелді.

\section{Тәжірибелік бөлім}

ГЭА және ММА негізінде тігілген сополимерлерді заттық иницирлеу әдісімен радикалдық полимерлеу арқылы алған. Инициатор ретінде азо-бис-изо май қышқылын қолданған. Тігілген сополимерлер алуда тігуші агент ретінде МБАА қолданған /4/.

Полимерлі гидрогельдердің бірқалыпты ісіну дәрежесі келесі формуламен анықталады:

$$
\alpha=\left(\mathbf{m}-\mathbf{m}_{0}\right) / \mathbf{m}_{0},
$$

мұндағы $\mathrm{m}$ - гидрогельдің бірқалыпты ісінгеннен кейінгі массасы, $\mathrm{m}_{0}$ құрғақ гельдің массасы.

Полимерлі гидрогельдердің салыстырмалы көлемін В-630 катетометр көмегімен өлшеп және $\mathrm{v} / \mathrm{v}_{0}$ қатынасымен бағалаған, мұндағы $\mathrm{v}_{0}$ және $\mathrm{v}$ - синтез кезіндегі үлгілердің көлемі және берілген жағдайдағы бірқалыпты ісіну күйі.

\section{Зерттеу нәтижелері және оларды талқылау}

Полимерлі гидрогельдерді қолдану аймағын арттыру үшін олардың иондық күште ісіну қабілеттері зерттелген. ГЭА-ММА сополимер гидрогелдерінің иондық күшінің әсерінен ісіну кинетикасын зерттеу барысында күшті кішімолекулалы электролит әсерінен ісіну қабілеттілігі кемитіні, яғни уақыт өткен сайын гидрогель жиырылып, коллапс күйіне тез жететіні анықталған (1сурет). Ол еріткіштің термодинамикалық қасиетінің төмендеуімен түсіндіріледі.

Гидрогельдердің құрамындағы гидрофобты ММА мөлшері де ісіну қабілетіне үлкен әсерін тигізеді. Судағы ісіну дәрежесі сияқты, кіші молекулалы күшті электролиттің қатысында гидрофобты 
ММА мөлшері артқан сайын 10-30 мол.\%-ға дейін, ісіну қабілеттілігі 3 тәулікте 7-ден 4-ке дейін кемиді.

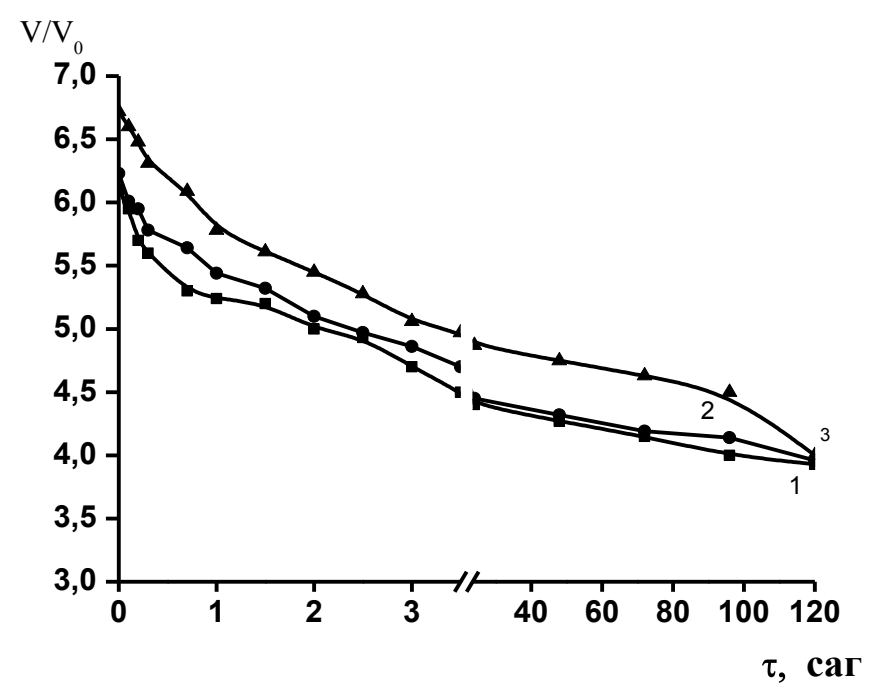

$$
\begin{gathered}
\text { БМК [ГЭА]:[ММА] }= \\
\text { 70:30 (1); 80:20 (2); } \\
\text { 90:10 (3) мол. } \% \\
\mu=0,05
\end{gathered}
$$

1-сурет. ГЭА-ММА сополимер гидрогелдерінің иондық күшінің әсерінен ісіну кинетикасы

2, 3-суреттерде иондық күштердің әсерін бағалау үшін полимерлі гидрогельдердің ісінуіне күшті кіші молекулалы электролиттің әр түрлі концентрациясын $\left(\mathrm{C}_{\mathrm{NaCl}}=0,01-0,1\right.$ моль/л) зерттеу нәтижелері көрсетілген. Алынған нәтижелер бойынша ГЭА-ММА полимерлі гидрогельдердің құрылымында гидрофобты ММА мөлшері артқан сайын иондық күш тепе-тең ісіну дәрежесіне тигізетін әсері зор, яғни иондық күш $\mu=0,02-0,1$ аралығында [ГЭА]:[MМА]= 90:10 мол. \% гидрогелінің шектік ісінуі өзгермей 4,5 шамасында болса, сәйкесінше, ММА мөлшері 30, 20 мол. \% гидрогельдерінің шектік ісіну дәрежесі төменгі молекулалық тұздың осы концентрация аралығында 4,0-ден 3,2-ге дейін төмендейді. Бұл кіші молекулалы тұздың әсерінен еріткіштің термодинамикалық сапасының кемуімен және гидрогельдің құрылымында ММА буындарының артуынан гидрофобты әрекеттесулер күшейіп, полимерлі гельдің коллапсқа ұшырауымен түсіндіріледі.
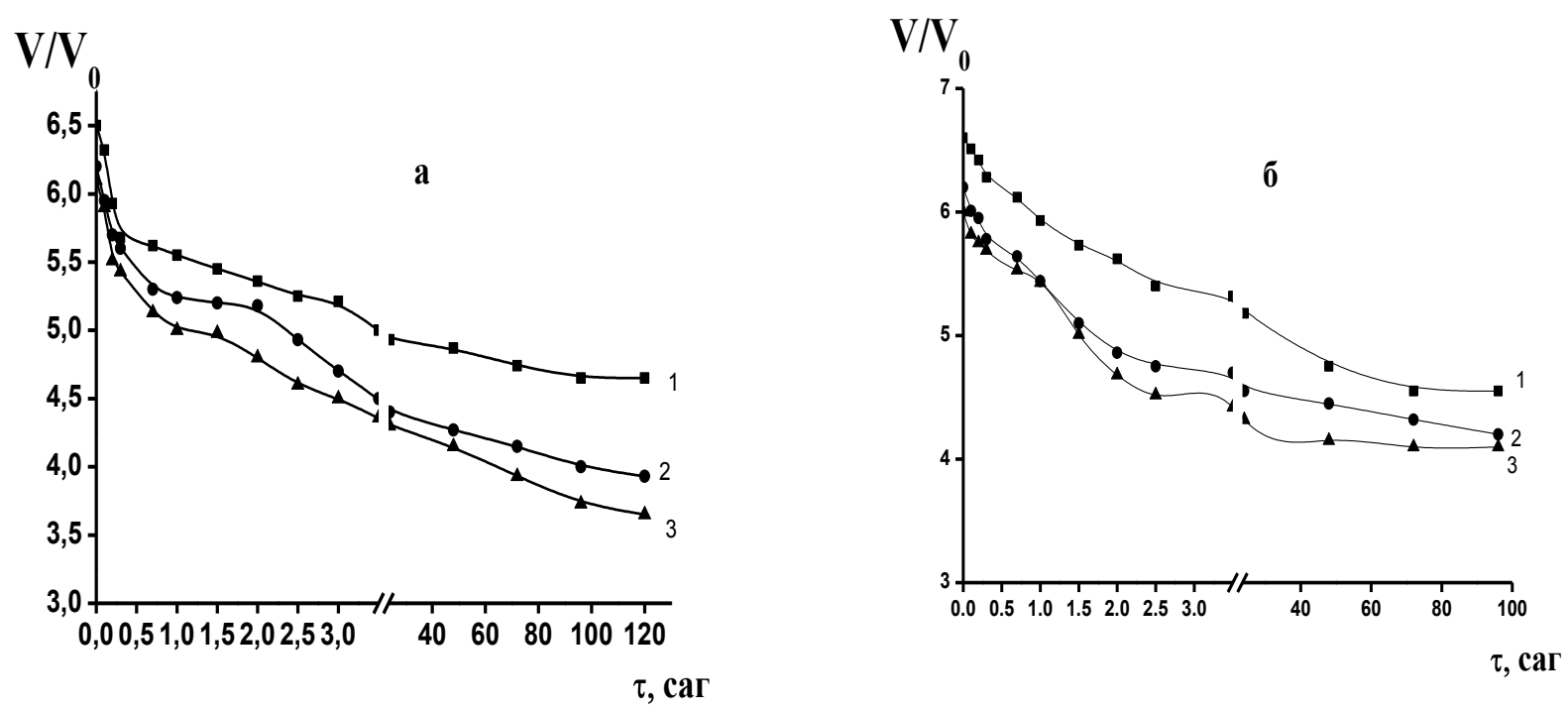


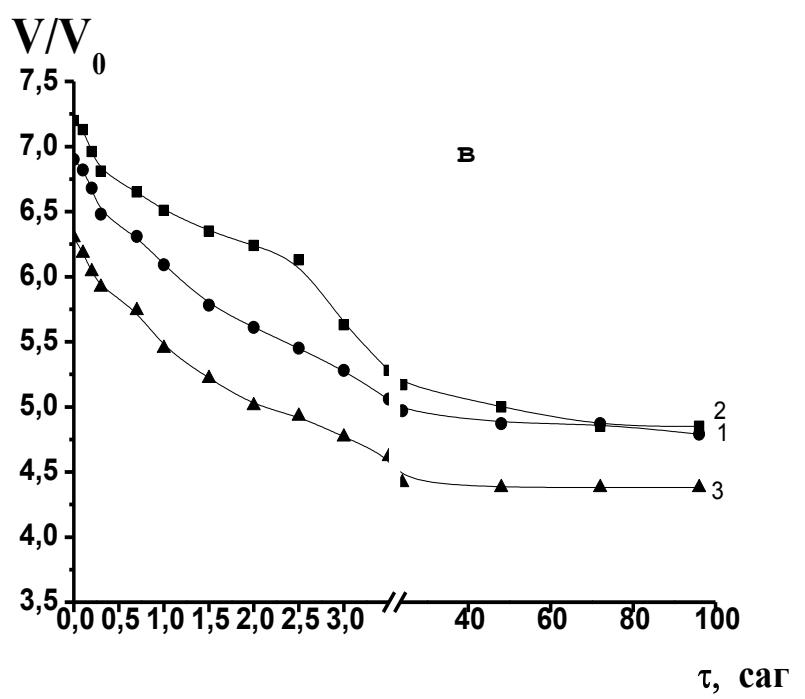

БМҚ [ГЭА]:[ММА] $=70: 30($ a); 80:20 (б); 90:10 (в) мол. \% $\mu=0.01$ (1); 0.05 (2); 0.1 (3); [TA] = 0,1 масс.\%

2-сурет. ГЭА-ММА гидрогелдерінің әртүрлі иондық күшінің әсерінен ісіну қабілетінің кинетикасы

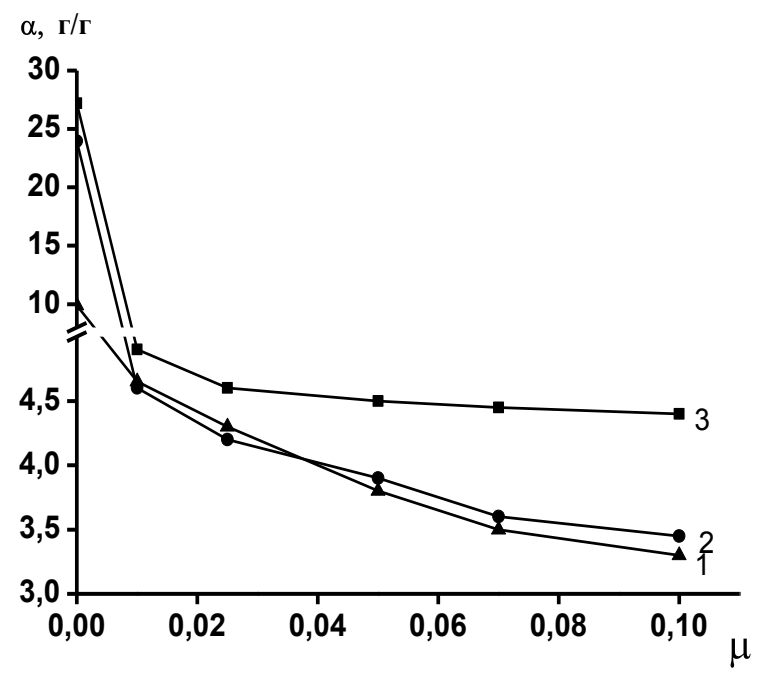

БМҚ [ГЭА]:[ММА] = 70:30 (1); 80:20 (2); $90: 10$ (3) мол. \%

$[\mathrm{TA}]=0,1$ масс. $\%$

3-сурет. ГЭА-ММА гидрогелдерінің ісіну дәрежесінің әр түрлі иондық күшінен тәуелділігі

Әдебиеттерден /5/ ионогенсіз ГЭА-БА, ГЭА-МА гидрогельдерінің иондық күштердің әсерінен жиырылу құбылысы артатыны белгілі. Синтезделген ГЭА-ММА полимерлі гидрогельдердің температураға сезімтал екенін біле отырып, иондық күште жиырылған гидрогельдерге температураның әсері зерттелінген. 4-суретте көрсетілгендей контракция күйіндегі гидрогельдерге 20-60 ${ }^{\circ} \mathrm{C}$ температура аралығында әсер еткенде ісінетіні анықталған. Бұл полимерлердің құрамындағы метилметакрилаттың аз мөлшерде болса да ионданатынын және гидрофобты әрекеттесулерге қарағанда жалпы қысымның иондық компоненті басым екенін көрсетеді. 


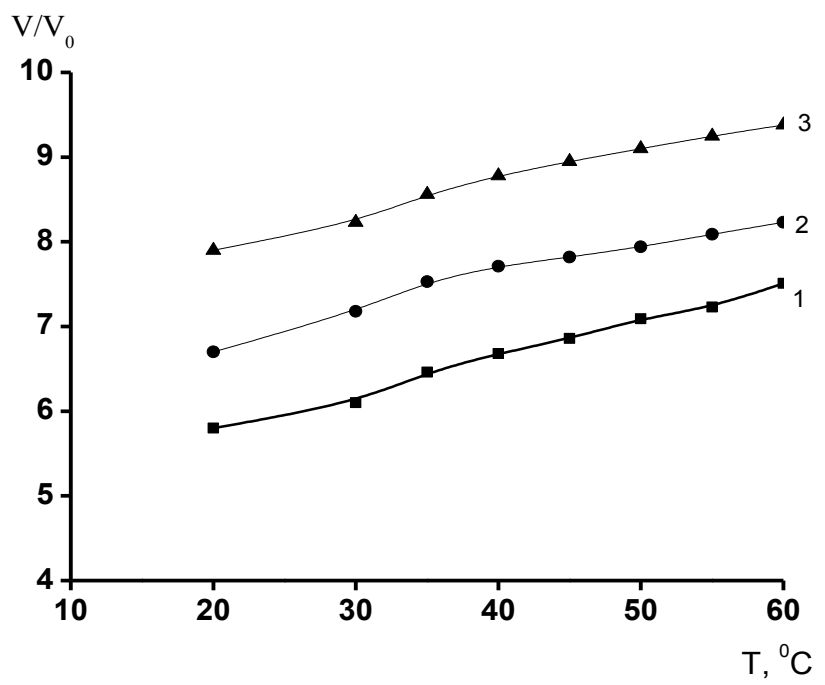

БМҚ [ГЭА]:[ММА] = 70:30 (1); $80: 20(2)$

90:10 (3) мол. \% $\mu=0.05$

$[\mathrm{TA}]=0,1$ масс. $\%$

4-сурет. ГЭА-ММА

гидрогелдерінің иондық күшінің әсерінен ісіну қабілетінің температурадан тәуелділігі

Қорыта келгенде, осы жұмыста ГЭА-ММА полимерлі гидрогельдердің ісіну дәрежесіне иондық күштің әсері зерттелген. Алынған нәтижелер бойынша ГЭА-ММА полимерлі гидрогельдерінің контракциясын тудыру үшін иондық күшті және бастапқы мономерлік қоспаның құрамын өзгерту арқылы қол жеткізуге болатыны дәлелденген.

\title{
Әдебиет
}

1 Тагер А.А., Сафронов А.П., Березюк Е.А., Галаев И.Ю. Гидрофобные взаимодействия и нижняя критическая температура водных растворов полимеров // Высокомолек. Соед. -1991.- Т. 33.А.№3. C. 572-577.

2 Лозинский В.И., Калинина Е.В., Гринберг В.Я., Гринберг Н.В., Чупов В.В., Платэ Н.А. Термочувствительные криогели на основе сшитого поли(N,N-диэтилакриламида) //Высокомолекул. соед. А.1997.39, 12.-С.1972-1978.

3 Галаев И.Ю. "Умные" полимеры в биотехнологии и медицине // Успехи химии.- 1995.-Т.64. №5.-С.505-524.

4 Нұрдәулет Еркінтай, Ә.Қ. Тоқтабаева, Г.А, Мун. 2-Гидроксиэтилакрилат пен метилметакрилат гидрогельдерінің синтезі және физика-химиялық қасиеттері // Вестник КазНУ. - 2008. - №4(52). - Б. 92-95.

5 Уркимбаева П.И., Пак А.Х., Мун Г.А., Нуркеева З.С. Синтез и характеристика новых термочувствительных сополимеров на основе 2-гидроксиэтилакрилата и метакрилата // Вестник КазНУ. Сер.хим., 2005. №1. - С.32-37.

\section{ВЛИЯНИЕ ИОННОЙ СИЛЫ НА НАБУХАЮЩУЮ СПОСОБНОСТЬ ГЕЛЕЙ 2-ГИДРОКСИЭТИЛАКРИЛАТА И МЕТИЛМЕТАКРИЛАТА}

\section{А.К. Токтабаева, Р.К. Рахметуллаева, Г.А. Мун}

Исследовано влияние ионной силь на степень набухания полимерных гидрогелей ГЭА-ММА. Показано, что контракции гидрогелей ГЭА-ММА можно достигнуть варьированием ионной силы и составом исходной мономерной смеси.

\section{INFLUENCE OF IONIC STRENGHT ON SWELLING OF 2-HYDROXYETYLAKRYLATE AND METHYLMETACRYLATE GELS}

\author{
A.K. Toktabayeva, R.K. Rahmetullaeva, G.A. Mun
}

Influence of ionic strength on swelling degree of polymeric HEA-MMA hydrogels was investigated. It is shown that contraction of HEA-MMA hydrogels can be reached by variation of ionic strength and structure of initial monomeric mix. 